\title{
Glutamate Promotes Proliferation of Striatal Neuronal Progenitors by an NMDA Receptor-Mediated Mechanism
}

\author{
Kelvin C. Luk, ${ }^{1}$ Timothy E. Kennedy, ${ }^{2}$ and Abbas F. Sadikot ${ }^{1}$ \\ ${ }^{1}$ Cone Laboratory and ${ }^{2}$ Center for Neuronal Survival, Department of Neurology and Neurosurgery, Montreal Neurological Institute, McGill University, \\ Montreal, H3A 2B4 Canada
}

Increasing evidence suggests that classical neurotransmitters play important roles in the development of the mammalian CNS. We used in vivo and in vitro models to identify a novel role for glutamate in striatal neurogenesis mediated by NMDA receptors. In utero exposure to NMDA receptor antagonists during striatal neurogenesis caused a dramatic reduction in the total number of adult striatal neurons. In contrast, embryos exposed to NMDA receptor antagonists immediately after the main period of neurogenesis showed no significant change in neuronal number in the adult striatum. In addition, examination of embryos shortly after NMDA receptor blockade revealed reduced proliferation in the lateral ganglionic eminence (LGE). In culture, dividing neuronal progenitors derived from the embryonic LGE showed marked reduction in 5'-bromodeoxyuridine (BrdU) uptake when exposed to NMDA receptor antagonists, indicating reduced DNA synthesis. Low concentrations of NMDA significantly increased proliferation, whereas high concentrations were toxic. AMPA-KA receptor antagonists had no significant effect on striatal neuroblast proliferation either in vivo or in vitro. These results support the hypothesis that glutamate plays a novel role during early development of the ventral telencephalon, promoting proliferation of striatal neuronal progenitors by an NMDA receptor-dependent mechanism. In contrast, previous findings suggest that proliferation of cortical progenitors derived from the dorsal telencephalon is regulated by activation of AMPA-KA but not NMDA receptors. Heterogeneous responses to glutamate in different germinal zones of the telencephalon may be an important mechanism contributing to generating neuronal diversity in the forebrain.

Key words: forebrain; striatum; neurogenesis; neurotransmitter; BrdU; stereology

\section{Introduction}

CNS development is the result of coordinated cell proliferation, migration, differentiation, synaptogenesis, and apoptosis (for review, see Sanes et al., 2000). Proliferation is determined by expression of distinct genetic programs and extracellular cues (Lillien, 1998; Edmund and Jessell, 1999). Differences in proliferative response to growth factors or neurotransmitters in embryonic germinal zones may be an important mechanism for achieving the appropriate number of neurons in different CNS regions (Lauder, 1993; Caviness and Takahashi, 1995; Levitt et al., 1997). Glutamate, the major excitatory neurotransmitter (Curtis et al., 1959; Watkins, 2000), is excitotoxic at high concentrations and implicated in CNS pathology (Olney, 1982; Choi, 1988). Increasing evidence suggests that glutamate plays novel roles in morphogenesis. Glutamate regulates migration, survival, differentiation, and neuritogenesis of neurons (Mattson and Kater, 1987; Simon et al., 1992; Rossi and Slater, 1993; Rakic and Komuro, 1995; Behar et al., 1996; Bhave and Hoffman, 1997; Dammerman and Kriegstein, 2000). Recent studies indicate that glutamate also plays an important modulatory role in proliferation of forebrain neuronal precursors (Cameron et al., 1995; LoTurco et al., 1995;

\footnotetext{
Received Aug. 26, 2002; revised Dec. 11, 2002; accepted Dec. 17, 2002.

This work was supported by operating grants from the Canadian Institutes for Health Research (CIHR) and the March of Dimes Birth Defects Foundation. The work is also supported by a studentship from the CIHR (K.C.L.) and scholarships from the (IHR (A.F.S., T.E.K.) and the Fonds de Recherche en Sante du Quebec. We thank Marie-Claude Bélanger for technical support.

Correspondence should be addressed to Dr. Abbas F. Sadikot, Room 109A, Montreal Neurological Institute, 3801 University Street, Montreal, Canada H3A 2B4. E-mail: sadikot@bic.mni.mcgill.ca.

Copyright $\odot 2003$ Society for Neuroscience $\quad 0270-6474 / 03 / 232239-12 \$ 15.00 / 0$
}

Sadikot et al., 1998; Haydar et al., 2000) (for review, see Contestabile, 2000; Arvidsson et al., 2001).

The mammalian telencephalon is derived from dorsal germinal zones that generate glutamatergic principal neurons of the cerebral cortex and ventral germinal zones that produce basal forebrain populations, including GABAergic principal neurons of the striatum (Holmgren, 1925; Fentress et al., 1981; Bayer, 1984; Marchand and Lajoie, 1986; Kawaguchi et al., 1995). With the exception of cortical GABAergic interneurons, derived mainly from the ventral telencephalon (de Carlos et al., 1996; Anderson et al., 1997; Tamamaki et al., 1997), most migrating neurons do not cross the corticostriatal boundary (Fishell et al., 1993). Dorsal and ventral telencephalic germinal zones express distinct transcription factors (Puelles and Rubenstein, 1993; Shimamura et al., 1995; Casarosa et al., 1999), exhibit distinct patterns of clonal heterogeneity (Halliday and Cepko, 1992; Acklin and van der Kooy, 1993), and may show unique morphogenetic responses to extracellular factors.

Glutamate is present in the telencephalic germinal zones during embryogenesis, and it exerts morphogenetic effects that vary with receptor subtype (Blanton and Kriegstein, 1991; Behar et al., 1999). Activation of AMPA-KA, but not NMDA, subclasses of ionotropic glutamate receptors alters proliferation in the cortical germinal zone (LoTurco et al., 1995; Haydar et al., 2000). Little is known about the role of glutamate in morphogenesis of the embryonic basal telencephalon. In utero NMDA receptor blockade markedly reduces proliferation of striatal GABAergic interneuron progenitors (Sadikot et al., 1998).

We hypothesize that proliferative responses to glutamate in 
dorsal and ventral telencephalic germinal zones are regionally specific. We investigate the influence of glutamate on proliferation of progenitors of striatal projection neurons, focusing on NMDA receptor activation using an in vivo model and proliferating primary neuronal cultures (Sadikot et al., 1998; Luk and Sadikot, 2001). We report that NMDA receptor activation is required for proliferation of striatal progenitors, whereas AMPAKA-mediated receptor mechanisms have no significant effect. These results suggest distinct reciprocal roles for NMDA and non-NMDA receptors in proliferation of neuronal progenitors in dorsal and ventral telencephalic germinal zones. This heterogeneous response to glutamate may be an important mechanism for generating neuronal diversity in the dorsal and ventral forebrain.

\section{Materials and Methods}

Ionotropic glutamate receptors and proliferation of striatal neuronal progenitors in vivo

Animals. Female Sprague Dawley rats (Charles River, LaSalle, Quebec, Canada) were coupled with males between 3:00 P.M. and 5:00 P.M. The first $24 \mathrm{hr}$ after coupling was designated as embryonic day zero (E0). A second group of females was coupled $48 \mathrm{hr}$ later to provide control animals, including dams matched for food and water intake with experimental groups. All animal procedures were performed in accordance with the Canadian Council on Animal Care guidelines for the use of animals in research.

In utero drug treatments for adult stereology. The NMDA receptor antagonists MK-801 (noncompetitive; $0.2 \mathrm{mg} \cdot \mathrm{kg}^{-1} \cdot \mathrm{d}^{-1}$ ) or CGS-19755 (competitive; $5 \mathrm{mg} \cdot \mathrm{kg}^{-1} \cdot \mathrm{d}^{-1}$; RBI, Natick, MA), or the AMPA-KA receptor antagonist 1, 2, 3, 4-tetrahydro-6-nitro-2, 3-dioxo-benzol(f)quinoxaline-7-sulfonamide (NBQX; $\left.10 \mathrm{mg} \cdot \mathrm{kg}^{-1} \cdot \mathrm{d}^{-1}\right)$ were administered to separate groups of rats. Drugs were dissolved in sterile normal saline and administered daily by intraperitoneal injection over a period of $4 \mathrm{~d}$ from either E15 to E18 or from E18 to E21. These time intervals correspond respectively to mainly proliferative or postproliferative periods for striatal neurons (Bayer, 1984; Marchand and Lajoie, 1986; van der Kooy and Fishell, 1987).

Food and water intake and weight for each animal was recorded daily. As controls, age-matched pregnant females were given daily intraperitoneal injections of saline $\left(1 \mathrm{ml} \cdot \mathrm{kg}^{-1} \cdot \mathrm{d}^{-1}\right)$ over identical $4 \mathrm{~d}$ periods as the drug-treated dams. In addition, pair-fed control groups were given access to the amount of food and water consumed by their drug-treated counterparts. A separate control group was given intraperitoneal saline injections during the period of interest and ad libitum access to food and water. After birth, five males were randomly chosen from each litter and killed between postnatal days 35 and 42 for histology by transcardial perfusion with $4 \%$ paraformaldehyde in phosphate buffer $\left(\mathrm{PFA} ; 4^{\circ} \mathrm{C}\right.$, $0.1 \mathrm{M}, \mathrm{pH} 7.4$ ).

Stereology. Coronal sections of the entire adult striatum were cut at 50 $\mu \mathrm{m}$ on a freezing microtome. After identifying the most rostral extent of the striatum, section collection was started randomly between the first and sixth section, as determined by a roll of dice. Serial free-floating sections were collected in PBS (0.1 M, pH 7.4) as separate sets so that each set contained every sixth serial section. One set of sections from each brain was processed using $0.1 \%$ cresyl violet as a Nissl stain. Sections were then cleared in xylene substitute and coverslipped with Permount (Fisher, Fair Lawn, NJ).

An unbiased stereological technique, the optical fractionator (Moller et al., 1990; West et al., 1996), was used to estimate the total number of neurons in the striatum and frontal agranular cortex as previously described (Luk and Sadikot, 2001). The apparatus used consisted of a light microscope (BX40; Olympus, Tokyo, Japan) coupled with a video camera (DC200; Dage, Michigan City, IN), motorized X-Y stage (BioPoint XYZ; LEP, Hawthorne, NY), $z$-axis indicator (MT12 microcator; Heidenhain, Traunreut, Germany), and a computer running Stereo Investigator software (Microbrightfield, Inc., Colchester, VT). The rostral and caudal limits of the reference volume were determined by the first and last coronal sections with visible caudate-putamen (neostriatum, dorsal striatum; approximately bregma 2.20 to $-2.60 \mathrm{~mm}$; Paxinos and

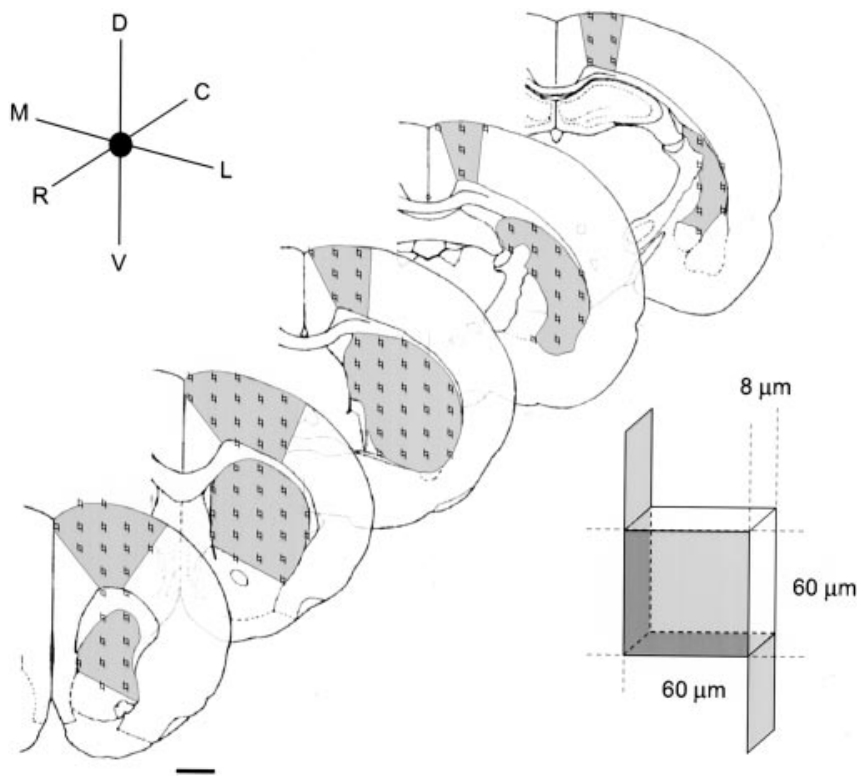

Figure 1. Stereological estimation of the number of striatal and motor cortical neurons. The total number of projection neurons in the adult rat striatum and frontal agranular cortex was estimated using the optical fractionator technique. Striatal and cortical reference volumes encompassed the first and last sections containing visible caudate-putamen, corresponding approximately to 2.20 to $-2.60 \mathrm{~mm}$ bregma (Zilles, 1985; Paxinos and Watson, 1986). Sections were cut at $50 \mu \mathrm{m}$ with every sixth section being examined. Counting frames were arranged $500 \mu \mathrm{m}$ apart to form a grid that was randomly superimposed over the reference area at each coronal level using the analysis software. Each counting frame measured $60 \times 60 \mu \mathrm{m}$ with a thickness of $8 \mu \mathrm{m}$ (inset). Exclusion lines and planes (shaded) were also implemented. Cell nuclei touching or falling within the counting frame were only recorded if there was no visible contact with any of the exclusion planes. Scale bar, $500 \mu \mathrm{m}$.

Watson, 1986). Every sixth serial section within this zone was examined, i.e., at $300 \mu \mathrm{m}$ intervals along the rostrocaudal axis. The corpus callosum, external capsule, lateral ventricle, globus pallidus, and anterior commissure were used as boundaries (Fig. 1). In the most rostral sections, the ventral striatum was excluded from analysis by a line drawn from the ventral tip of the lateral ventricle to the dorsal border of the piriform cortex, corresponding to an angle of $20-30^{\circ}$ below the horizontal axis. In more caudal sections, the caudate-putamen borders included the external capsule, globus pallidus, bed nucleus of the stria terminalis, the substantia innominata, and the dorsal amygdala. Stereology was also performed for the motor cortex in the same sections. Areas corresponding to Fr1 and Fr2 (frontal agranular cortex) were delineated with the help of an atlas (Zilles, 1985). The granular somatosensory cortex was excluded from analysis. Surface areas of each region of interest were estimated from tracings of the neostriatum at $4 \times$ magnification using the software. Volumes of the reference space were estimated using the Cavalieri method (Gundersen and Jensen, 1987).

Systematic random sampling of neurons in the neostriatum was performed by randomly translating a grid with $500 \times 500 \mu \mathrm{m}$ squares onto the section of interest using the software (Fig. 1). At each intersection of grid lines a $60 \times 60 \mu \mathrm{m}$ counting frame with exclusion lines was then applied (Fig. 1). All randomly assigned sample sites were then examined using a $100 \times$ objective (oil; numerical aperture, 1.3). Neurons were distinguished using the nucleus as a unique identifier, and glial cells were excluded on the basis of morphology and by counting only profiles $>7$ $\mu \mathrm{m}$ in diameter according to previously described criteria (Dam, 1992; Oorschot, 1996; Luk and Sadikot, 2001). Only neurons falling within the counting frame without contact with the exclusion lines were enumerated. Objects seen in the counting frame were only counted if they came into focus within a predetermined 8 - $\mu \mathrm{m}$-thick optical dissector positioned $2 \mu \mathrm{m}$ below the surface of the mounted section as indicated by the microcator. Each optical dissector therefore consisted of a $60 \times 60 \times 8$ $\mu \mathrm{m}$ brick with three exclusion planes (Fig. 1, inset). Calculated estimates 
of the total number of neurons in each neostriatal and cortical reference volume were determined using the Stereo Investigator software. Statistical analysis was performed by one-way ANOVA $(\alpha=0.01)$ with the Student-Newman-Keuls post hoc test (SNK) for comparison between groups.

Analysis of embryos after drug treatment. The immediate effects of receptor antagonists on cell proliferation in vivo were examined in embryos. Separate groups of timed pregnant rats were given MK-801 $\left(0.2 \mathrm{mg} \cdot \mathrm{kg}^{-1} \cdot \mathrm{d}^{-1}\right)$, CGS-19755 $\left(5 \mathrm{mg} \cdot \mathrm{kg}^{-1} \cdot \mathrm{d}^{-1}\right)$, NBQX $\left(10 \mathrm{mg} \cdot \mathrm{kg}^{-1} \cdot \mathrm{d}^{-1}\right)$, or saline via intraperitoneal injection on E15 and E16. On E16, drug administration was followed $1 \mathrm{hr}$ later by a single injection of $\mathrm{BrdU}(50 \mathrm{mg} / \mathrm{kg})$. Embryos were removed after a further $12 \mathrm{hr}$ by Cesarean section, decapitated, and fixed overnight in $4 \%$ PFA. Heads were then transferred to $10 \%$ formalin, dehydrated, and embedded in paraffin. Embryonic brains in paraffin blocks were sectioned at $5 \mu \mathrm{m}$ with a microtome. Antigen retrieval was achieved by heating sections in citrate buffer $(0.01 \mathrm{M}, \mathrm{pH} 6.0)$ for $15 \mathrm{~min}$ at $90^{\circ} \mathrm{C}$. Sections were then exposed to $2 \mathrm{~N} \mathrm{HCl}$ for $1 \mathrm{hr}$, followed by three washes in PBS (5 min each), and then incubated overnight with a monoclonal antibody against BrdU (1:10, Becton Dickinson, Franklin Lakes, NJ). Cells were then washed three times with PBS and labeled using the avidin-biotin-complex (ABC) peroxidase method by incubating for $1 \mathrm{hr}$ with biotinylated goat anti-mouse IgG secondary antibody (1:200) followed by ABC solution (Vector Laboratories, Burlingame, CA). The final reaction was revealed by exposing cells to a solution (NiDAB) containing Tris buffer $(0.05 \mathrm{M}, \mathrm{pH} 7.6)$, nickel ammonium sulfate $(3.7 \mathrm{mg} / \mathrm{ml}), 3,3^{\prime}$-diaminobenzidine (DAB; $0.25 \mathrm{mg} /$ $\mathrm{ml})$, and $0.0006 \%$ hydrogen peroxide. Sections were then counterstained with nuclear fast red, dehydrated, and coverslipped in Permount.

To determine the immediate effects of treatment on proliferation, BrdU-immunoreactive nuclei were quantified in coronal sections at the level of the ganglionic eminence. The striatal and cortical periventricular zones were delineated by a $100 \mu \mathrm{m}$ wide box placed $\sim 100 \mu \mathrm{m}$ from the cortical striatal angle (see Fig. $3 a, b$ ). The first $50 \mu \mathrm{m}$ from the ventricular surface was arbitrarily designated as the ventricular zone (VZ), whereas the area from 100 to $200 \mu \mathrm{m}$ was considered the subventricular zone (SVZ). Proliferative nuclei were counted through the entire thickness of the section, and the results were expressed as a percentage of nuclei that were BrdU+.

\section{Ionotropic glutamate receptors and proliferation of striatal} neuronal progenitors in vitro

Microdissection and preparation of proliferative striatal cultures. Cultures were prepared from E15 rat embryos using techniques similar to those previously described (Ikeda et al., 1997; Ivkovic et al., 1997; Ventimiglia and Lindsay, 1998). The lateral ganglionic eminence (LGE) that gives rise to the striatum anlage (Bayer, 1984; Deacon et al., 1994) was microdissected in cold magnesium-free HBSS (Sigma, St. Louis, MO). The dissected tissue was then incubated in trypsin and DNase at $37^{\circ} \mathrm{C}$ and centrifuged at $1200 \mathrm{rpm}$ for $5 \mathrm{~min}$ in DMEM (Sigma) containing 10\% fetal bovine serum. The pellet was resuspended in Neurobasal medium supplemented with B27 (Life Technologies, Burlington, Ontario, Canada). Cells were dissociated by passing through a series of fire-polished Pasteur pipettes of decreasing caliber. Viable cells were then counted by Trypan Blue exclusion, diluted in Neurobasal/B27 medium (Bottenstein, 1985; Brewer, 1995) containing $2 \mathrm{~mm}$ L-glutamine and penicillin-streptomycin. Cells were then plated on 8-well chamber slides precoated with polyD-lysine (Becton Dickinson) at a density of $2 \times 10^{5}$ cells $/ \mathrm{cm}^{2}$ and incubated at $37^{\circ} \mathrm{C}$ in an air: $\mathrm{CO}_{2}(20: 1)$ mixture for $1-5 \mathrm{~d}$ in vitro (DIV).

Treatment and BrdU incorporation. Twenty-four hours after initial plating, cells in individual slide chambers were exposed to either MK-801 $(2 \mu \mathrm{g} / \mathrm{ml})$, CGS-19755 (20 $\mu \mathrm{g} / \mathrm{ml})$, NMDA $(0.1-100 \mu \mathrm{M})$, NBQX (10 $\mu \mathrm{M})$, or vehicle control. Drugs were prepared immediately before addition to the culture medium. To label cells passing through S-phase, BrdU (20 $\mu \mathrm{g} / \mathrm{ml}$; Sigma) was added to each chamber either 4 or $24 \mathrm{hr}$ after treatment. Cells were then fixed for $20 \mathrm{~min}$ with cold 4\% PFA either $2 \mathrm{hr}$ or $12 \mathrm{hr}$ after addition of BrdU, and processed for immunocytochemistry.

Immunocytochemistry. BrdU uptake by proliferating cells was revealed by immunostaining (Gratzner, 1982). Briefly, cells were permeabilized in cold acetone-methanol (1:1), washed in PBS, and denatured in $2 \mathrm{~N} \mathrm{HCl}$ for $20 \mathrm{~min}$. The cells were then washed with PBS, sodium borate $(0.1 \mathrm{M})$, followed by another PBS wash. Anti-BrdU antibody (1:10; Becton Dickinson) was added and incubated overnight at $4^{\circ} \mathrm{C}$. Cells were then washed three times with PBS and labeled with an Alexa 594-conjugated goat anti-mouse IgG antibody (1:500; Molecular Probes, Eugene, OR).

To characterize cell types, cultures were also immunostained for neuron-specific $\beta$ III-microtubulin (TuJ1; 1:500; Babco, Richmond, CA) or microtubule-associated protein-2 (MAP-2; 1:1000; Sigma) as early or late neuronal markers, respectively (Lee et al., 1990; Memberg and Hall, 1995), or for glial fibrillary acidic protein (GFAP; 1:1000; Sigma). Cells were counterstained with 4', 6-diamidino 2-phenylindole dihydrochloride (DAPI; $1 \mu \mathrm{g} / \mathrm{ml}$ in $\mathrm{H}_{2} \mathrm{O}, 15 \mathrm{~min}, 37^{\circ} \mathrm{C}$ ) to reveal cell nuclei.

To determine whether proliferating neuroblasts express NMDA receptor subunits, double-labeling for BrdU and NMDA receptor subunits was performed in culture. After initial pretreatment and incubation with anti-BrdU antibody (see above), cells were incubated overnight in primary antibodies for NMDA receptor subunits. Primary antibodies were dissolved in PBS containing 0.3\% Triton X-100 and 1\% normal goat serum and washed in PBS $(3 \times 5 \mathrm{~min})$. Polyclonal antibodies for NR1 (1:500; Transduction Laboratories, Lexington, KY), NR2A (1:400; Chemicon, Temecula, CA), NR2B (1:500; Sigma), and NR2C (1:250; Chemicon) were used. Cells were then incubated with an appropriate secondary antibody conjugated to either Alexa-488 or -594 (1:500) for 1 $\mathrm{hr}$, then washed in PBS $(5 \times 5 \mathrm{~min})$. For double-labeling of NR1 and NR2A, a monoclonal antibody for NR1 (1:1000; Chemicon) was used.

Analysis. Fluorescently labeled cells were visualized under a fluorescence microscope using a $40 \times$ objective and the appropriate filters. Density of cells and nuclei was determined in 40-50 random fields generated using the Stereo Investigator software. Results were compared by ANOVA as described above.

\section{Results}

\section{Exposure to NMDA receptor antagonists reduces} proliferation of neostriatal neuronal precursors in vivo

To determine whether ionotropic glutamate receptors mediate proliferation in the developing mammalian striatum, rat embryos were exposed in utero to competitive and noncompetitive NMDA receptor antagonists. Drugs were administered either during proliferative (E15-E18) or mainly postproliferative (E18E21) period for striatal neurogenesis (Smart and Sturrock, 1978; Bayer, 1984; Marchand and Lajoie, 1986; van der Kooy and Fishell, 1987). To quantify total neuron number in the striatum and motor cortex of adult offspring, we applied the optical fractionator technique to cresyl violet-stained brain sections. This quantitative method allowed for efficient and unbiased estimates of total neuronal number within the entire striatal or cortical reference volume. Stereology is preferred over nonstereological estimates based on profile counts, because the latter method is subject to bias resulting from changes in either the volume of the reference space or the size of the object counted (Moller et al., 1990; West et al., 1996). Changes in total neuronal count and striatal volume were compared based on analysis of sections obtained from drug-treated and control animals.

The estimated number of neurons per striatum in rats receiving only the saline vehicle during the proliferative (E15-E18) or postproliferative (E18-E21) phases was $2.58 \pm 0.10$ million and $2.54 \pm 0.12$ million, respectively (Fig. $2 a$ ) (all data represented as mean \pm SEM). These estimates are in agreement with results from previous studies using similar stereological methods to quantify principal neurons in the rodent striatum (Dam, 1992; Oorschot, 1996). In comparison with pair-fed control animals, administration of NMDA receptor antagonists during the maximal proliferative period for projection neurons (E15-E18) resulted in a $38-54 \%$ reduction of striatal neuronal number (Fig. $2 a)$. One-way ANOVA revealed significantly decreased neuron 

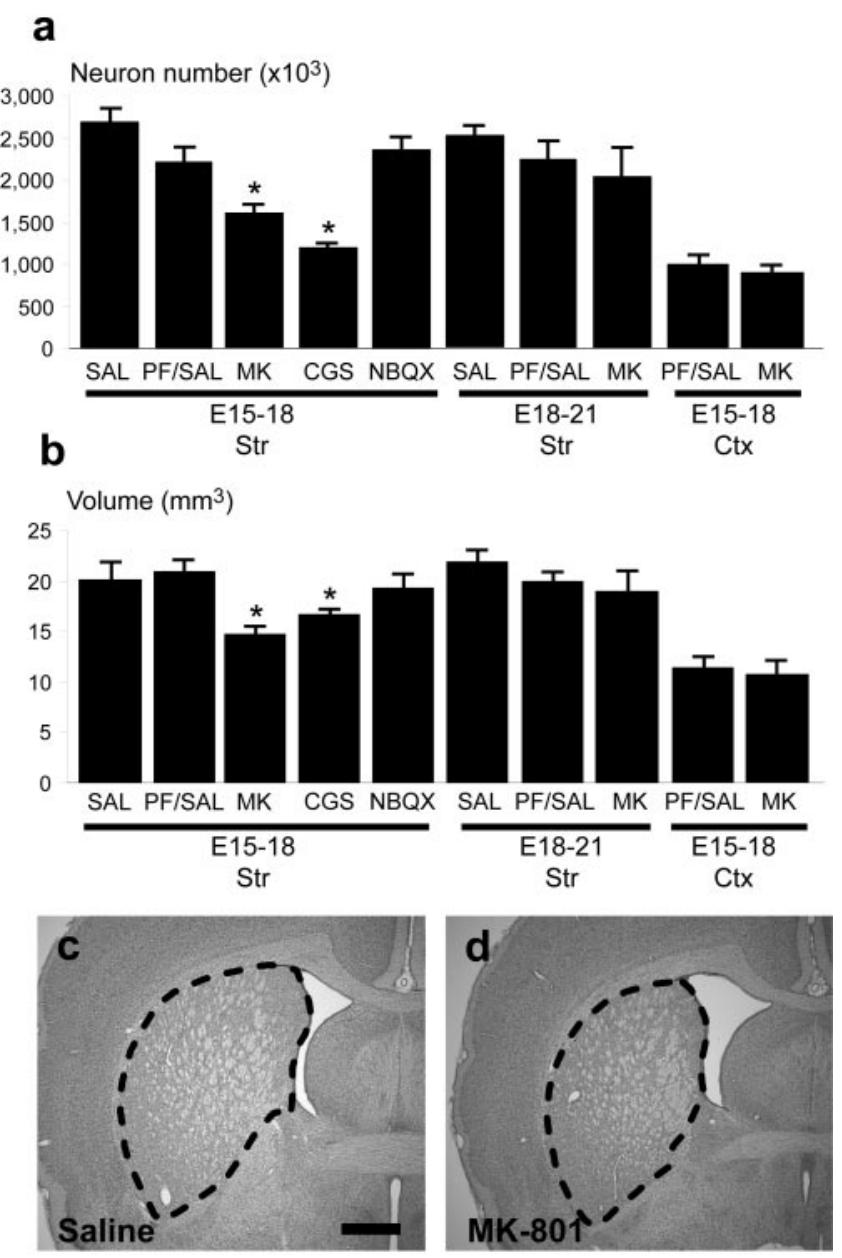

Figure 2. Total striatal and cortical neuron number and volume after treatment with glutamate receptor antagonists. Stereological estimates of the total number of striatal and cortical neurons for all experimental groups are shown $(a)$. Treatment with glutamate receptor drugs extended between either E15-E18 or E18-E21, corresponding to the main proliferative and postproliferative periods, respectively, for neostriatal neurons. Striatal neuron number in rats was significantly reduced after administration of noncompetitive and competitive NMDA glutamate receptor antagonists (MK-801 and CGS 19755, respectively) when compared with saline (SAL) and pair-fed saline (PF/SAL) control groups (all data expressed as mean $\pm S E M ; F_{(7,24)}=$ $17.01 ;{ }^{*} p<0.01$ vs pair-fed control). Effects were statistically significant only after treatment between E15 and E18, but not between E18 and E21. Treatment with MK-801 did not significantly alter neuron number in the frontal agranular cortex, suggesting that NMDA receptormediated effects on proliferation are restricted to the striatum in this model. Striatal volumes (b) also showed a significant decrease after MK-801 or CGS-19755 treatment, likely reflecting the loss of neurons $\left(F_{(7,24)}=12.32 ;{ }^{*} p<0.01\right.$ vs pair-fed control). Treatment with NBQX did not change neuron number or striatal volume, suggesting that the observed effect is mediated by NMDA, but not AMPA-KA receptors. Decreased striatal volume and neuron number after exposure to MK-801 was visible at the level of the anterior commissure in cresyl violet-stained sections $(c, d)$. Scale bars, $500 \mu \mathrm{m}$.

numbers in rats treated with either the noncompetitive antagonist MK-801 (1.61 \pm 0.06 million) or the competitive antagonist CGS-19755 (1.20 \pm 0.08 million) in comparison with both pairfed $(2.13 \pm 0.14$ million $)$ and saline $(2.58 \pm 0.10$ million $)$ controls. Animals receiving either NMDA antagonist during the proliferative period also exhibited significantly reduced neostriatal volumes (MK-801: $14.8 \pm 0.49 \mathrm{~mm}^{3}$; CGS: $16.9 \pm 0.32 \mathrm{~mm}^{3}$ ), compared with pair-fed $\left(19.9 \pm 1.1 \mathrm{~mm}^{3}\right)$ and saline $(20.1 \pm 1.2$ $\mathrm{mm}^{3}$ ) control groups (Fig. $2 b$ ). These reduced volumes likely reflect reductions in striatal neuron number.

In contrast, in utero exposure to MK-801 during the predom- inantly postproliferative period for striatal projection neurons (E18-E21) did not result in statistically significant changes in striatal neuron number $(2.0 \pm 0.17$ vs $2.11 \pm 0.13$ million $)$ (Fig. $2 a)$ or striatal volume $\left(18.95 \pm 0.28\right.$ vs $\left.20.1 \pm 0.92 \mathrm{~mm}^{3}\right)$ (Fig. $2 b$ ) in comparison with the pair-fed control group. Decreased neuron number after prenatal NMDA receptor antagonist exposure is therefore attributable mainly to reduced proliferation of striatal neuroblasts or precursors. To determine if proliferation of striatal neuroblasts is dependent on non-NMDA receptormediated glutamatergic mechanisms, as is the case in the dorsal telencephalic germinal zone (Haydar et al., 2000), dams were exposed to NBQX during the prenatal proliferative period. NBQX failed to significantly alter striatal volume or neuron number indicating that AMPA-KA receptor blockade does not influence proliferation of neuroblasts derived from the prenatal ventral telencephalon (Fig. 2a,b). Additionally, administration of MK-801 from E15 to E18 did not significantly alter neuron number or volume in the frontal agranular cortex (Fig. 2a,b), suggesting that the observed effects of the NMDA receptor antagonists are regionalized to the ventral telencephalon.

Progenitors of medium spiny GABAergic projection neurons likely account for the observed NMDA-mediated proliferative effects because this population comprises $90 \%$ of rat striatal neurons (Kitai, 1981; Smith and Bolam, 1990; Kawaguchi et al., 1995). Decreases in proliferation of precursors of other minor striatal neuronal subpopulations may also account for a small proportion of observed changes, although these were not distinguished using Nissl stains. For example, parvalbumin-positive GABAergic interneurons, which comprise $\sim 1 \%$ of striatal neurons (Luk and Sadikot, 2001), likely contribute to the observed changes, because our previous studies indicate that proliferation of precursors of this subpopulation is also positively influenced by NMDA receptor activation (Sadikot et al., 1998).

To account for possible nutritional effects, pair-fed groups (E15-E18 and E18-E21) matched for food and water intake were used as controls. Striatal neuronal counts and volumes were lower in pair-fed groups compared with saline controls (Fig. 2), but the decreases did not reach statistical significance, suggesting that nutritional effects were minor in these experiments.

\section{NMDA receptor blockade reduces proliferation in the ganglionic eminence}

To observe the effects of NMDA receptor blockade on striatal development more directly, proliferation in the lateral ganglionic eminence was examined in embryos shortly after exposure to MK-801. The final administration of the antagonist was followed by $12 \mathrm{hr}$ BrdU exposure to label cells in S-phase. Analysis of the ventricular zones of the ganglionic eminence revealed an $18 \%$ decrease in the percentage of BrdU-labeled nuclei with respect to saline controls after MK-801 exposure (Fig. $3 c-e$ ). Overall nuclear density in the LGE was similar in both treated and untreated animals (data not shown). The percentage of nuclei positive for BrdU in the subventricular zone was comparable in both MK801-treated and control animals. Our in vivo data collectively indicate that NMDA, but not AMPA-KA, ionotropic glutamate receptors mediate an important proliferative effect on striatal neuroblasts or precursors. Interestingly, in the developing dorsal telencephalon, AMPA-KA activation increases DNA synthesis in cortical progenitors in the ventricular zone, whereas NMDA receptor activation has no effect on proliferation (Haydar et al., 2000). 

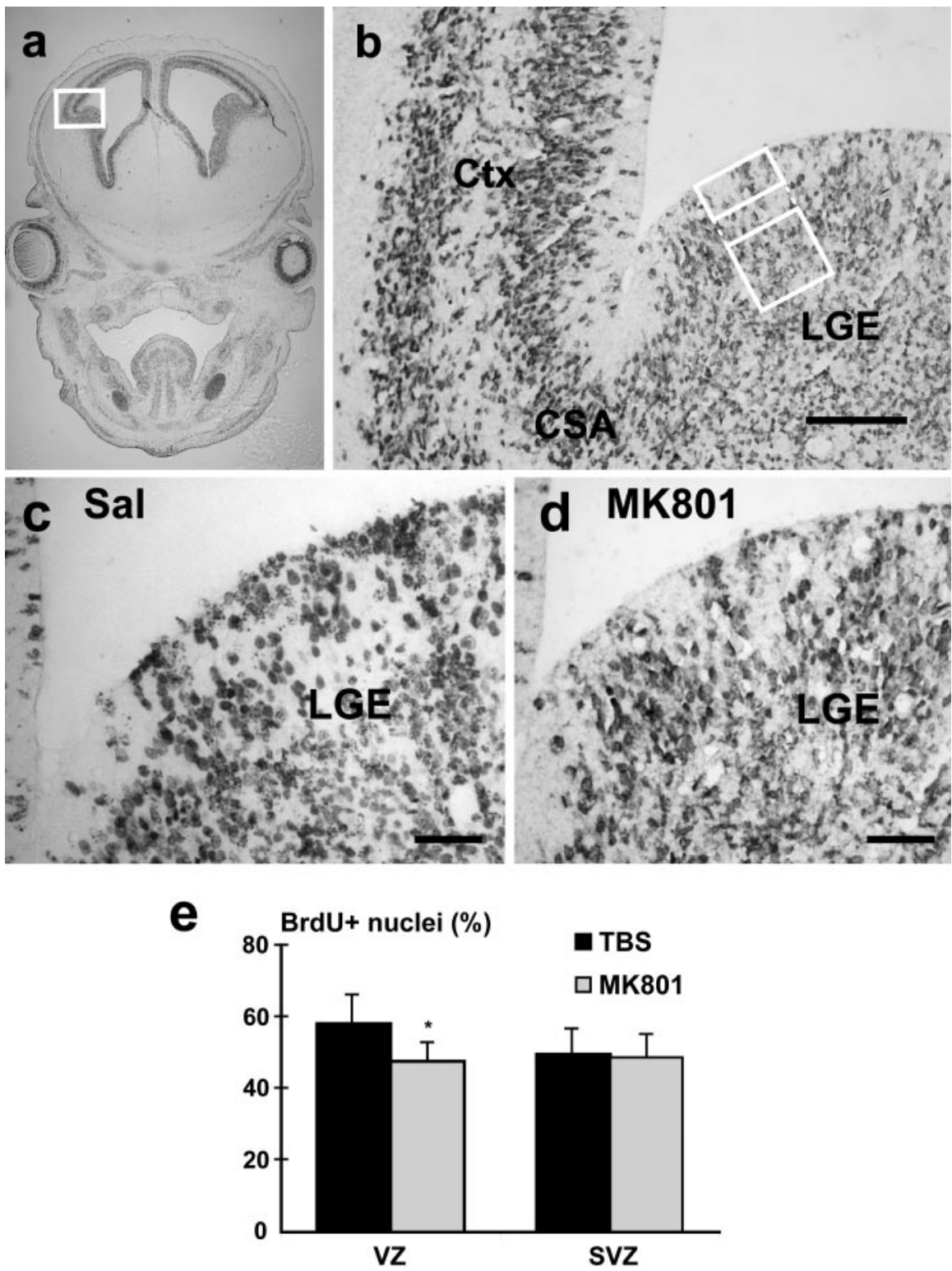

Figure 3. Effects of MK-801 treatment on embryonic basal forebrain proliferative zones. Embryonic rats were given MK-801 $(0.2 \mathrm{mg} / \mathrm{kg})$ on E15 and again on E16, followed by BrdU injection $1 \mathrm{hr}$ later. Embryos were fixed $12 \mathrm{hr}$ later at E16.5, sectioned, and stained using a monoclonal antibody against BrdU. $a, b$, The periventricular striatal proliferative zones were delineated $100 \mu \mathrm{m}$ from the cortical striatal angle (CSA). An area 100- $\mu \mathrm{m}$-wide and 50- $\mu \mathrm{m}$-deep from the ventricular surface was assigned as the ventricular zone (VZ). The subventricular zone (SVZ) was defined as a $100 \times 100 \mu \mathrm{m}$ area located $50 \mu \mathrm{m}$ ventral to the VZ (b). BrdU + nuclei in the two zones were quantified after treatment with saline (TBS) and MK-801. c, d, Photomicrographs showing BrdU uptake near the CSA region after treatment. After treatment with the NMDA receptor antagonist, the percentage of BrdU + nuclei was reduced in the VZ but not SVZ. $\left(e ;{ }^{*} p<0.01 ; n=4\right)$. $C t x$, Cortex; $L G E$, lateral ganglionic eminence. Scale bars: $b, 100$ $\mu \mathrm{m} ; c, d, 40 \mu \mathrm{m}$.

\section{Characterization of proliferating striatal neuroblasts in vitro} Dissociated cultures of proliferating striatal neuroblasts derived from E15 LGE were incubated in serum-free Neurobasal/B27 medium for 1-5 DIV (Ivkovic et al., 1997; Ventimiglia and Lindsay, 1998). Immunochemical markers revealed that the cultures were predominantly neuronal in composition (Fig. 4). A TuJ1 antibody that recognizes neuron-specific $\beta$ III-microtubulin, was used to label cells committed to a neuronal lineage (Geisert and Frankfurter, 1989; Moody et al., 1989). This antigen is not expressed by astrocytes or oligodendrocytes and is an early marker of neuronal differentiation, including neuroblasts undergoing mitosis and postmitotic neurons (Lee et al., 1990; Easter et al.,
1993; Memberg and Hall, 1995; Jacobs and Miller, 2000). MAP-2, a specific marker for postmitotic and differentiated neurons (Johnson and Jope, 1992), was also used. Using DAPI as a nuclear counterstain, $42 \%$ of cells in 2 DIV cultures were positive for $\mathrm{TuJ} 1$, and $62 \%$ of cells were positive for MAP-2 (Matus et al., 1980). At 4 DIV, the majority of cells were also NeuN-positive (data not shown). GFAP staining cultures indicated that glia comprised $<2 \%$ of the total cell population. These results are in agreement with previous reports suggesting that GABAergic medium spiny neurons and their precursors make up the majority of cells in these early cultures, with a minority of interneurons and glia (Ivkovic et al., 1997; Ventimiglia and Lindsay, 1998; Petersen et al., 2000). The results are also consistent with evidence that forebrain gliogenesis (with the exception of radial glia) occurs in the late prenatal and early postnatal periods (Schultze et al., 1974).

To quantify cell proliferation, cultures were exposed to the thymidine analog BrdU for a period of $24 \mathrm{hr}$ after 1, 2, or 4 DIV. The proportion of nuclei that were positive for BrdU was maximal during the first $48 \mathrm{hr}$ in vitro and decreased to low levels by $96 \mathrm{hr}$ (data not shown). This is similar to the proliferative chronology in vivo (Bayer, 1984; Marchand and Lajoie, 1986; van der Kooy and Fishell, 1987).

The presence of NMDA receptors in vitro was confirmed by staining with antibodies against subunits of the receptor heteromer. The NR1, NR2A, and NR2B subunits were detected in proliferative cultures by immunofluorescence (Fig. 5); however, no NR2C staining was detected. Immunoblots of lysates prepared from 2 DIV cultures showed similar results (data not shown). In double-labeling experiments, the NR1 subunit, which is common to functional NMDA receptors (Monyer et al., 1994), was detected in $\sim 76 \%$ of BrdU+ cells after $4 \mathrm{hr}$ of exposure (Fig. $5 a, b)$. Smaller subsets of BrdU+ cells also expressed NR2A (Fig. 5c,d) and NR2B subunits (data not shown). These results indicate that dividing neuroblasts may express a functional form of NMDA receptor.

NMDA receptor activation promotes proliferation of striatal neuronal precursors in vitro

To identify the role of NMDA receptors in neuroblast proliferation, 1 DIV embryonic striatal cultures were exposed to NMDA antagonists (MK-801, CGS-19755), NMDA (1-100 $\mu \mathrm{M})$, or vehicle. Similar cultures were also exposed to NBQX to compare NMDA and AMPA-KA receptor-mediated effects. Cultures were incubated in medium containing drug or vehicle for $24 \mathrm{hr}$, followed by a brief $2 \mathrm{hr}$ exposure to BrdU before fixation (Fig. 6). 

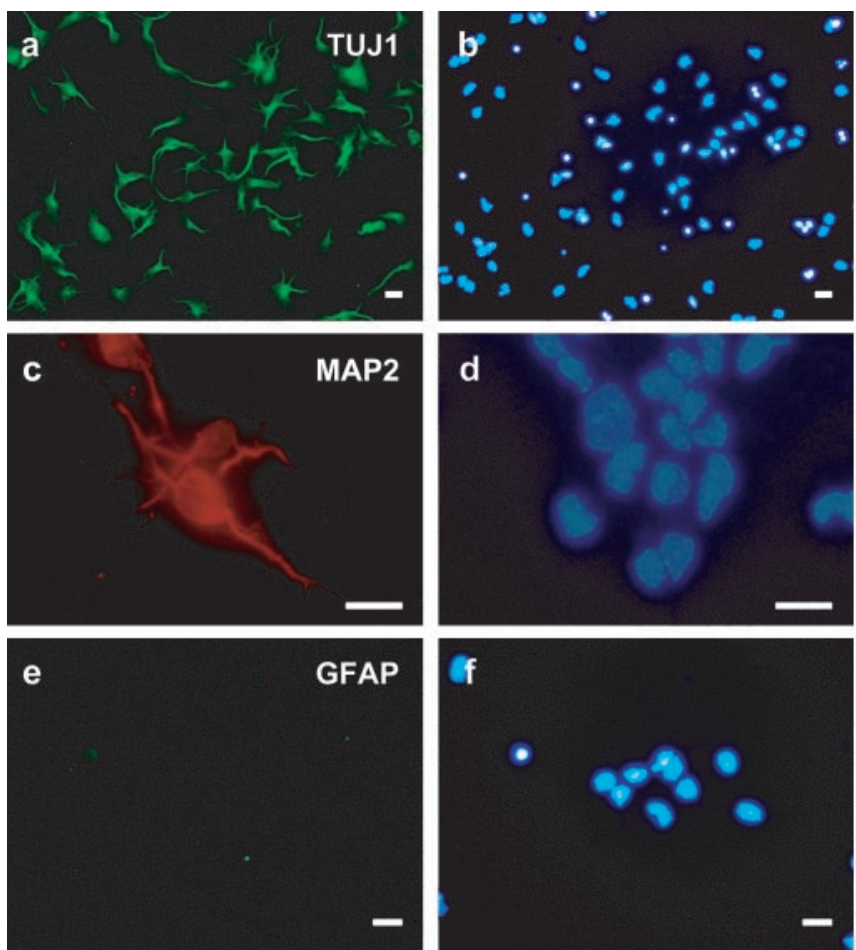

Figure 4. Embryonic striatal cultures. Cells obtained from rat ganglionic eminence at E15 were cultured in serum-free defined medium. Neurons were immunostained against TUJ1 ( $a$ ) and MAP2 ( $c$ ) after 2 DIV. GFAP staining did not reveal the presence of any astrocytes, suggesting a population of predominantly neuronal cells in vitro (e). DAPI counterstaining for $a, c$, and $e$ is found in $b, d$, and $f$, respectively. Scale bars, $10 \mu \mathrm{m}$.

BrdU labeling in this preparation was therefore limited to proliferating populations that were in S-Phase at the time BrdU was added. The presence of either MK-801 or CGS-19755 reduced the percentage of BrdU+ nuclei to $<50 \%$ of control levels (Fig. $6 a$ ). To further establish that NMDA receptors mediate the effects of glutamate on cell proliferation, cultures were exposed to varying concentrations of NMDA.

Exposure to $1 \mu \mathrm{M}$ NMDA resulted in a $29 \%$ increase in proportion (and density, data not shown) of BrdU+ nuclei (Fig. 6a). However, progressively higher concentrations of NMDA $(10,100$ $\mu \mathrm{M})$ resulted in decreases in the proportion of both BrdU+ nuclei (Fig. 6a) and cells positive for neuronal markers (MAP-2 or TuJ-1) (Fig. 6b,c), in keeping with the expected excitotoxic effects at these doses (Koroshetz et al., 1990). Despite marked reduction in BrdU uptake, cultures exposed to NMDA antagonist for $24 \mathrm{hr}$ showed no significant reduction in MAP2 + cell number, suggesting that maturation and survival of postmitotic neurons was unaltered. On the other hand, the density of neurons expressing the earlier neuronal marker TuJ1+ decreased significantly after exposure to CGS-19755 or MK-801 (Fig. 6b). The contrasting results with the two markers are in keeping with the observation that MAP-2 is expressed in the processes of more mature neurons (Johnson and Jope, 1992), whereas TuJ1 expression is initiated during the final mitosis of neuronal progenitors (Memberg and Hall, 1995; Jacobs and Miller, 2000). Reduction in the number of $\mathrm{TuJ} 1+$ neurons may therefore reflect decreased proliferation of neuroblasts giving rise to early postmitotic TuJ1+ populations. These results collectively suggest that NMDA-mediated glutamatergic mechanisms have a marked influence on neuroblast proliferation, but not on survival of postmitotic neurons. Exposure to NBQX had no effect on the proportion of cells with BrdU+
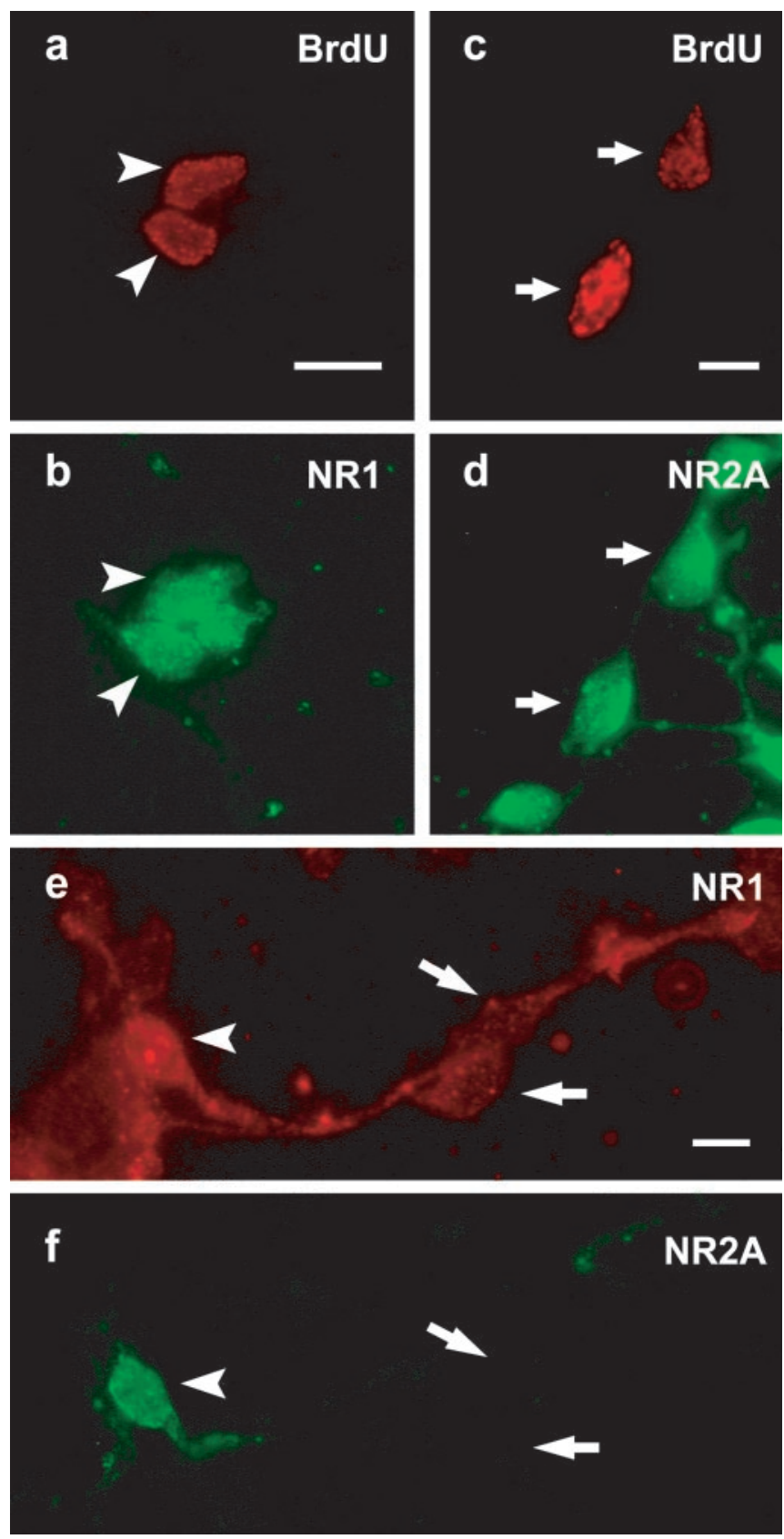

Figure 5. NMDA receptor profile of embryonic striatal cultures. Embryonic neostriatal cultures were fixed at $1 \mathrm{DIV}$ after $4 \mathrm{hr}$ BrdU exposure and immunostained using antibodies against various NMDA receptor subunits. A large number of cells were positively stained for the NR1 subunit. A small subset of NR1-immunoreactive cells colocalized with BrdU, indicating that proliferative or recently postmitotic cells express functional NMDA receptor subunits $(a, b)$. Staining using polyclonal antibodies against NR2 subunits also revealed a significant number of BrdU + cells expressing the NR2A subunit $(c, d)$. Coexpression of the NR2A subunit was also detected in a subpopulation of NR1-positive cells (e,f; indicated by arrowheads). However, no staining for the NR2C subunit was observed. Scale bars: $a, c, 10 \mu \mathrm{m} ; e, 12 \mu \mathrm{m}$.

nuclei, or TuJ1+ and MAP-2+ cells, indicating lack of an effect of AMPA-KA on proliferation of striatal progenitors, in keeping with our in vivo results.

To determine whether NMDA-mediated glutamatergic mechanisms influence cell proliferation after short-term exposure, 1 DIV cultures were incubated with the same agonist/antagonists for only $4 \mathrm{hr}$ followed by a $2 \mathrm{hr}$ pulse of BrdU before fixation (Fig. 7a). Given estimated cell cycle times of 10-20 hr for 
a

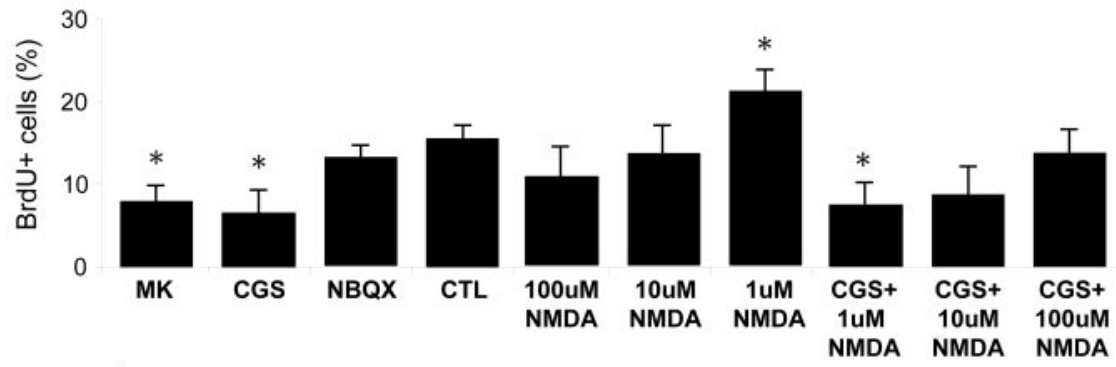

b

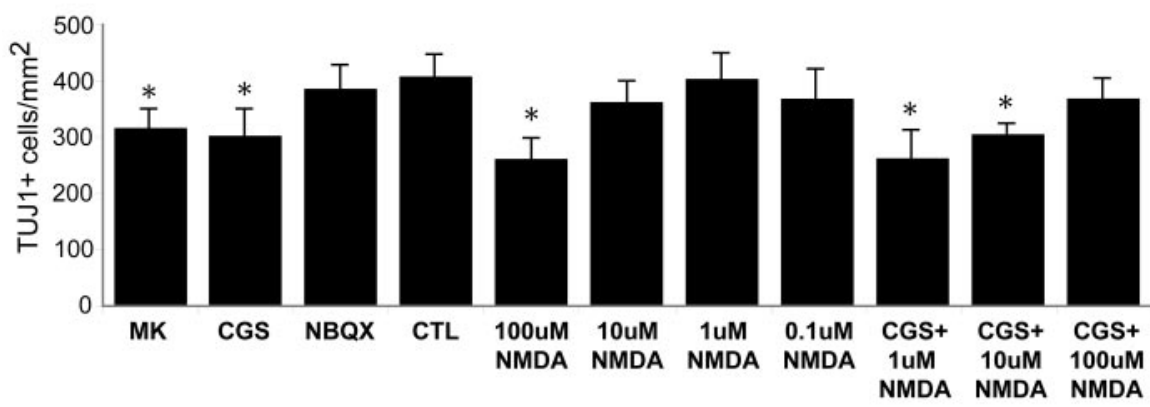

C
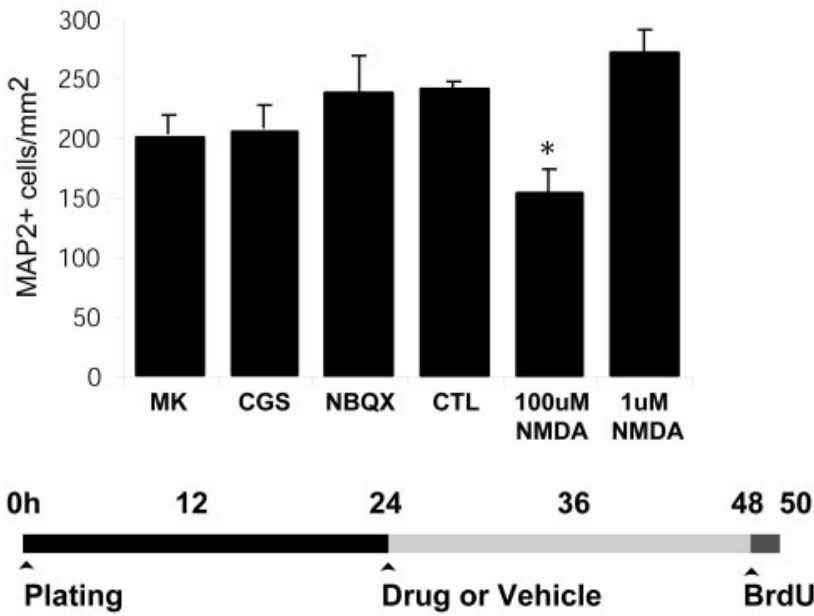

Figure 6. Effects of glutamate receptor antagonists and NMDA after $24 \mathrm{hr}$ exposure. Striatal cultures of 1 DIV were exposed to different ionotropic glutamate receptor antagonists, NMDA, or vehicle control. $a$, Treatment duration was $24 \mathrm{hr}$ and was followed by $2 \mathrm{hr}$ exposure to BrdU (20 $\mu \mathrm{g} / \mathrm{ml})$ and fixation in PFA (diagram). Treatment with MK-801 or CGS 19755 significantly reduced the proportion of nuclei incorporating BrdU with respect to control cultures. Effect of the competitive antagonist (CGS) could be countered by addition of NMDA. Addition of $100 \mu \mathrm{M}$ NMDA to CGS-treated cultures restored BrdU uptake close to normal levels. Exposure to NBQX did not alter BrdU uptake, suggesting that NMDA but not AMPA receptor blockade results in decreased proliferation. In cultures in which only the agonist was added, BrdU uptake was inversely proportional to NMDA concentration. At $1 \mu \mathrm{M}_{\text {, }}$ NMDA significantly upregulated proliferation, whereas increasing doses exhibited toxic effects. $B$, The proportion of Tuj1-positive cells were also quantified after each treatment. Exposure to MK-801 or CGS 19755 reduced the proportion of TUJ1 cells, suggesting that production of early postmitotic neurons was reduced after receptor blockade. Tuj 1 cell number also decreased after treatment with $100 \mu \mathrm{m}$ NMDA. c, MAP2 + cell number did not alter significantly after treatment, with the exception of NMDA at excitotoxic concentrations, suggesting that the short-term survival of more mature neurons was not affected by the agents added. Data expressed as mean \pm SEM $\left(n=3 ;{ }^{*} p<0.01\right.$ vs control).

striatal progenitors (Acklin and van der Kooy, 1993; Bhide, 1996) this experiment has the advantage of minimizing possible fluctuations in cell number caused by proliferation or apoptosis during the treatment period.

As in the previous experiment, exposure to either MK-801 or CGS-19755 resulted in a significant decrease in the percentage of
BrdU+ nuclei ( -35 and 33\%, respectively) compared with control cultures (Fig. 7a), indicating that effects on neuroblast proliferation can be detected within $4 \mathrm{hr}$ after initial receptor blockade. In keeping with the hypothesis that NMDA positively influences proliferation, exposure to $1 \mu \mathrm{M}$ NMDA also increased the percentage of cells with BrdU+ nuclei, although this value did not reach strong statistical significance (Fig. 7a) $(p<0.03)$. The density of MAP- $2+$ and TuJ1+ neurons after exposure to either glutamate receptor antagonists or low concentrations of NMDA remained unchanged (Fig. $7 b, c)$. Unaltered neuronal density is expected because the treatment period is within the cell cycle time for striatal neuroblasts. However, the addition of $100 \mu \mathrm{M}$ NMDA to cultures reduced the density and number of both $\mathrm{TuJ} 1+$ and BrdU+ nuclei, respectively, indicating toxicity. As in previous experiments, there was no significant change in BrdU uptake after application of NBQX.

To determine whether the reduction in proliferation after NMDA receptor blockade is reversible, NMDA was added at various concentrations to cultures treated with the competitive receptor antagonist CGS-19755. A dose-dependent rescue was observed in which NMDA concentration was directly proportional to the number of BrdU+ nuclei (Fig. 7a). With the addition of $100 \mu \mathrm{M}$ NMDA, BrdU uptake in CGS-19755-treated cultures recovered to $80 \%$ of control levels. However, no recovery in proliferation was observed with application of MK-801, in keeping with the noncompetitive nature of this receptor antagonist (data not shown). These experiments collectively suggest that NMDAmediated, but not AMPA-KA-mediated, glutamatergic mechanisms promote proliferation of striatal neuronal progenitors.

\section{Discussion}

In the present study, we identify a novel role for the classical neurotransmitter glutamate in promoting proliferation of neuronal precursors derived from the germinal zone of the ventral telencephalon. Using an in vivo model, we demonstrate that proliferation of progenitors of the principal neurons of the striatum is dependent on activation of NMDA glutamate receptors. We further investigated ionotropic glutamate receptor-mediated effects in proliferative cultures derived from the lateral ganglionic eminence, the main source of striatal progenitors. Our results indicate that NMDA receptor-mediated glutamatergic activity promotes proliferation of striatal neuronal progenitors. Conversely, AMPA-KA-mediated mechanisms have no significant 
effect on proliferation of striatal progenitors. In contrast, previous studies indicate that cortical neuronal progenitors proliferate in response to activation of AMPAKA, but not NMDA receptors. We propose that the germinal epithelium of the embryonic telencephalon is spatially heterogeneous with respect to proliferative response to glutamate. Regional variation in neurotransmitter effects on proliferation in the germinal zones of the telencephalon may be an important novel mechanism for generating neuronal phenotypic diversity in the forebrain.

Glutamate promotes proliferation in the ventral telencephalon by an NMDA receptor-mediated mechanism

Little is known about factors governing proliferation of neuronal progenitors of the striatum, the major derivative of the ventral telencephalon. Growth factors including epidermal growth factor, basic fibroblast growth factor, and transforming growth factor $\beta$ modulate proliferation in the developing ventral forebrain (Reynolds and Weiss, 1992; Temple and Qian, 1995; Cavanagh et al., 1997; Ciccolini and Svendsen, 1998). Recent evidence suggests that amino acid neurotransmitters play an important role in proliferation and survival of forebrain neurons. $\mathrm{GABA}_{\mathrm{A}}$ receptor activation, which can depolarize embryonic neurons (Cherubini et al., 1991), mediates survival, but not proliferation of striatal neuronal progenitors (Ikeda et al., 1997; Luk and Sadikot, 2001). The role of glutamate-induced depolarizing activity in early morphogenesis of the striatum remains primarily unexplored.

The present results indicate that nonNMDA ionotropic receptors do not influence proliferation of striatal neuronal precursors. However, the in vivo and in vitro evidence suggests that NMDA receptors play an important role in proliferation of ventral telencephalon-derived striatal progenitors. Prenatal exposure to NMDA antagonists results in a marked decrease in neuronal proliferation. In utero exposure to NMDA antagonists during the postproliferative period has no effect on neuronal survival, in keeping with previous work (Ikonomidou et al., 1999). Interestingly, postnatal exposure to NMDA antagonists dramatically increases developmental cell death, suggesting NMDA exerts a trophic influence during the major period of striatal neuronal apoptosis (Ikonomidou et al., 2000).

The GABAergic projection neurons, which comprise $90 \%$ of striatal neurons (Smith and Bolam, 1990), are a major target of NMDA-mediated proliferative effects. Previous work suggests that NMDA also promotes proliferation of other striatal popula-

b

C
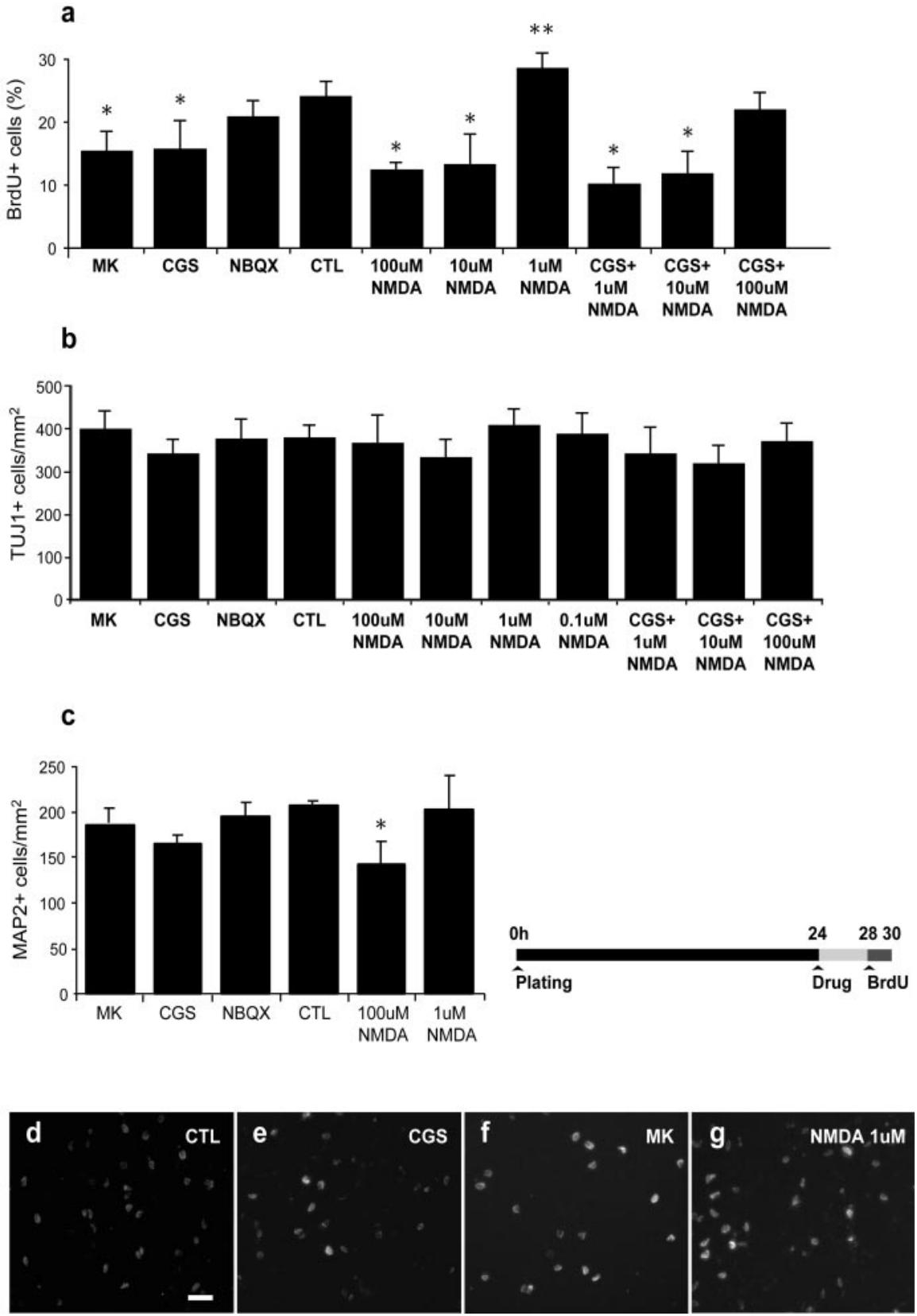

Figure 7. Effects of glutamate receptor antagonists and NMDA after $4 \mathrm{hr}$ exposure. Striatal cultures of $1 \mathrm{DIV}$ were exposed to various ionotropic glutamate receptor antagonists, NMDA, or vehicle control for $4 \mathrm{hr}$, followed by $2 \mathrm{hr}$ exposure to BrdU (timeline). Because treatment duration was much shorter than the expected cell cycle time for these cultures, the changes in cell population number caused by drugs should be minimized. a, After $4 \mathrm{hr}$ treatment with MK-801 or CGS 19755, BrdU incorporation was significantly reduced, suggesting that NMDA receptor blockade exerts its influence on proliferation within this period. BrdU uptake in cultures treated with CGS 19755 could be restored to near control levels by adding increasing concentrations of NMDA. As in previous culture experiments, exposure to NBQX did not alter BrdU uptake. Exposure to NMDA at high concentration (100 $\mu \mathrm{m})$ resulted in decreased numbers of BrdU + nuclei, whereas at $1 \mu \mathrm{m}$, proliferation was above control levels. $b, c$, No significant alterations in the proportion of Tuj $1+(b)$ or MAP2 $+(c)$ cells were observed after any of the treatments (data expressed as mean \pm SEM, $n=3 ;{ }^{*} p<0.01 ;{ }^{* *} p<0.05$ vs control). $d-g$, Photomicrographs of BrdU-labeled cells in vitro after exposure to NMDA and receptor antagonists. Scale bar, $8 \mu \mathrm{m}$.

tions such as parvalbumin-positive GABAergic interneurons (Sadikot et al., 1998) that originate in the medial ganglionic eminence (Lavdas et al., 1999; Marin et al., 2000). Because striatal projection neurons arise mainly from the LGE, NMDA receptors mediate proliferation of neuronal precursors arising from both major germinal zones of the ventral telencephalon. Recent evidence suggests a large proportion of neocortical (de Carlos et al., 
1996; Anderson et al., 1997; Tamamaki et al., 1997; Marin et al., 2000; Parnavelas, 2000) and hippocampal GABAergic interneurons (Pleasure et al., 2000) are derived from the ventral telencephalon. NMDA-dependent proliferation may thus be a common property of all forebrain GABAergic interneuronal precursors. Whether NMDA effects are restricted to GABAergic neurons or extend to cholinergic and somatostatinergic subtypes produced in the ventral germinal zones remains to be addressed.

\section{Proliferative responses to NMDA are regionally diverse in forebrain germinal zones}

With the exception of GABAergic interneurons (Marin et al., 2000), cells generated in the germinal zones of the dorsal and ventral telencephalon remain primarily separate during forebrain morphogenesis (Fishell et al., 1993). Furthermore, the dorsal and ventral zones express distinct transcription factors, some of which are implicated in neurogenesis (Shimamura et al., 1995; Metin et al., 1997; Casarosa et al., 1999). Cells in the proliferative epithelium generating the cortex or striatum on either side of the corticostriatal boundary (Holmgren, 1925; Puelles et al., 2000; Inoue et al., 2001) may therefore show distinct responses to the extracellular environment. Regional differences in proliferative behavior of neuronal progenitors are evident in response to amino acid neurotransmitters (Cameron et al., 1998; Contestabile, 2000). In cortex, both glutamate and GABA regulate proliferation of neuronal precursors (LoTurco et al., 1995; Haydar et al., 2000). AMPA-KA receptors mediate altered DNA synthesis in cortical progenitors (LoTurco et al., 1995), but have no effect on proliferation of striatal progenitors. Such regional differences are also apparent with respect to NMDA-mediated responses. NMDA receptor activation promotes proliferation of striatal precursors, has no effect on proliferation of neocortical progenitors (LoTurco et al., 1995), and reduces proliferation of hippocampal granule cell precursors (Cameron et al., 1995; Seki and Arai, 1995).

Recent evidence in the dorsal telencephalon suggests that proliferative responses may vary between cellular subtypes. For example, activation of AMPA-KA receptors increases proliferation of neuronal precursors in the ventricular zone, but decreases proliferation in the subventricular zone (Haydar et al., 2000), a domain that generates mainly glia (Sidman et al., 1959; Altman, 1969). Our data suggest that NMDA effects on proliferation of neuronal progenitors in the ganglionic eminence occur mainly in the ventricular zone, with no effect in the subventricular zone. It would be of interest to determine whether distinct responses also exist among neuronal and glial precursors derived from the ventral germinal zones.

\section{Potential mechanisms mediating NMDA effects on proliferation}

Calcium entry after NMDA receptor activation mediates a variety of developmental effects in the CNS (Ascher and Nowak, 1988; Yuste and Katz, 1991), including cell survival (Balazs et al., 1988; Bhave and Hoffman, 1997; Ikonomidou et al., 2000), neurite outgrowth (Mattson and Kater, 1987), and synaptic plasticity (Stevens et al., 1994). The downstream intracellular mechanisms that may couple NMDA receptor-mediated calcium entry to DNA synthesis in striatal progenitors are unknown. Extracellular regulated kinases (ERKs) have been observed to mediate proliferative responses invoked by a variety of growth factors (Finkbeiner and Greenberg, 1996; Fukunaga and Miyamoto, 1998). With respect to classical neurotransmitter effects, proliferation in cortical progenitors after muscarinic receptor activation appears to be mediated by phosphatidylinositol-3-kinase (PI3) and ERK signaling pathways ( $\mathrm{Li}$ et al., 2001). NMDA receptor activation in striatal neurons has been demonstrated to initiate this pathway in a PI3-dependent manner (Vincent et al., 1998; Schwarszschild et al., 1999; Perkinton et al., 2002). Components of this cascade (e.g., CaM-kinase, Ras, Mek, ERK1/2, and PI3) can be localized to glutamatergic postsynaptic densities (Husi et al., 2000). The ERK-PI3 pathway is therefore a strong candidate mechanism coupling NMDA receptor activation to DNA synthesis in striatal progenitors.

Contrasting proliferative responses to NMDA receptor activation during CNS morphogenesis may be the result of spatial and temporal differences in glutamate receptor expression (Goebel and Poosch, 1999; Kovacs et al., 2001). Both NMDA and non-NMDA ionotropic receptors are widely expressed in the prenatal rat telencephalon and exhibit developmentally regulated patterns of subunit expression that determine distinct functional effects (Misgeld and Dietzel, 1989; Monyer et al., 1994; Landwehrmeyer et al., 1995; Wullner et al., 1997; Nansen et al., 2000). In vitro, cells derived from the LGE exhibit NMDA responses (Vincent et al., 1998). Here, we provide evidence for NR1 and NR2 subunits in proliferating neuroblasts, suggesting a role for a functional channel in the observed events. Developmental variations in local glutamate concentration (Haydar et al., 2000), or interaction between NMDA receptors and other growth factors (Dobbertin et al., 2000; Roceri et al., 2001) may also contribute to variations in functional effects. Finally, distinct intracellular downstream mechanisms coupling NMDA receptor activation to the cell cycle machinery may also underlie variations in proliferative responses (for review, see Platénik et al., 2000).

\section{Relevance to developmental abnormalities}

Disruptions in forebrain development because of pathological responses to amino acid neurotransmitters may be relevant to a wide variety of human diseases, including schizophrenia (Harrison, 1999), prenatal brain injury from trauma or ischemia (Vexler and Ferriero, 2001), cortical dysplasias (Flint and Kriegstein, 1997), and developmental disorders after prenatal exposure to drugs of abuse (e.g., PCP, ethanol; Deutsch et al., 1998; Tabakoff et al., 1991), sedatives, anticonvulsants, and anesthetics (Reich and Silvay, 1989; Jevtovic-Todorovic et al., 1998; Morrell, 1999). The importance of NMDA-mediated glutamatergic mechanisms was recently highlighted in the pathogenesis of fetal alcohol syndrome (FAS; Ikonomidou et al., 2000). Magnetic resonance imaging in human FAS reveals markedly reduced volumes in the striatum as well as the cerebral cortex and cerebellum (Mattson et al., 1994; Archibald et al., 2001). Ethanol acts at NMDA and $\mathrm{GABA}_{\mathrm{A}}$ receptor sites (Lovinger et al., 1989; Hoffman et al., 1989; Mihic, 1999). Based on previous work, alcohol-induced activation of $\mathrm{GABA}_{\mathrm{A}}$ receptors would not be expected to mediate a proliferative effect on striatal neuronal precursors (Ikeda et al., 1997; Luk and Sadikot, 2001). In rodent models, exposure to MK-801 or alcohol results in a dramatic increase in postnatal apoptosis in the striatum, supporting the hypothesis that NMDA receptors mediate a trophic effect (Ikonomidou et al., 1999, 2000). Our current data suggests that alcohol and other NMDA antagonists may also impair neuroblast proliferation, and therefore contribute to abnormal striatal morphogenesis as early as the first trimester of human pregnancy (O'Rahilly and Müller, 1994). In conclusion, temporal and spatial variations in morphogenic responses to glutamate play an important role in normal development and may contribute to distinct abnormalities of forebrain development in a wide variety of pathologies. 


\section{References}

Acklin SE, van der Kooy D (1993) Clonal heterogeneity in the germinal zone of the developing rat telencephalon. Development 118:175-192.

Altman J (1969) Autoradiographic and histological studies of postnatal neurogenesis. IV. Cell proliferation and migration in the anterior forebrain, with special reference to persisting neurogenesis in the olfactory bulb. J Comp Neurol 137:433-457.

Anderson SA, Shi L, Rubenstein LJ (1997) Interneuron migration from basal forebrain to neocortex, dependence on Dlx genes. Science 278:474-476.

Archibald SL, Fennema-Notestine C, Gamst A, Riley EP, Mattson SN, Jernigan TL (2001) Brain dysmorphology in individuals with severe prenatal alcohol exposure. Dev Med Child Neurol 43:148-154.

Arvidsson A, Kokaia Z, Lindvall O (2001) N-methyl-D-aspartate receptormediated increase of neurogenesis in adult rat dentate gyrus following stroke. Eur J Neurosci 14:10-18.

Ascher P, Nowak L (1988) The role of divalent cations in the N-methyl-Daspartate responses of mouse central neurones in culture. J Physiol (Lond) 399:247-266.

Balazs R, Jorgensen OS, Hack N (1988) N-methyl-D-aspartate promotes the survival of cerebellar granule cells in culture. Neuroscience 27:437-451.

Bayer SA (1984) Neurogenesis in the rat neostriatum. Int J Dev Neurosci 2:163-175.

Behar TN, Li Y, Tran HT, Ma W, Dunlap V, Scott CA, Barker JL (1996) GABA stimulates chemotaxis and chemokinesis of embryonic cortical neurons via calcium-dependent mechanisms. J Neurosci 16:1808-1818.

Behar TN, Scott CA, Greene CL, Wen X, Smith SV, Maric D, Liu QY, Colton CA, Barker JL (1999) Glutamate acting at NMDA receptors stimulates embryonic cortical neuronal migration. J Neurosci 19:4449-4461.

Bhave SV, Hoffman PL (1997) Ethanol promotes apoptosis in cerebellar granule cells by inhibiting the trophic effect of NMDA. J Neurochem 68:578-586.

Bhide PG (1996) Cell cycle kinetics in the embryonic mouse corpus striatum. J Comp Neurol 374:506-522.

Blanton MG, Kriegstein AR (1991) Appearance of putative amino acid neurotransmitters during differentiation of neurons in embryonic turtle cerebral cortex. J Comp Neurol 310:571-592.

Bottenstein JE (1985) Growth and differentiation of neural cells in defined media. In: Cell culture in the neurosciences (Bottenstein JE and Sato G, eds), pp 3-14. New York: Plenum.

Brewer GJ (1995) Serum-free B27/neurobasal medium supports differentiated growth of neurons from the striatum, substantia nigra, septum, cerebral cortex, cerebellum, and dentate gyrus. J Neurosci Res 42:674-683.

Cameron HA, McEwen BS, Gould E (1995) Regulation of adult neurogenesis by excitatory input and NMDA receptor activation in the dentate gyrus. J Neurosci 15:4687-4692.

Cameron HA, Hazel TG, McKay RD (1998) Regulation of neurogenesis by growth factors and neurotransmitters. J Neurobiol 36:287-306.

Casarosa S, Fode C, Guillemot F (1999) Mash1 regulates neurogenesis in the ventral telencephalon. Development 126:525-534.

Cavanagh JF, Mione MC, Pappas IS, Parnavelas JG (1997) Basic fibroblast growth factor prolongs the proliferation of rat cortical progenitor cells in vitro without altering their cell cycle parameters. Cereb Cortex 7:293-302.

Caviness VS Jr, Takahashi T (1995) Proliferative events in the cerebral ventricular zone. Brain Dev 17:159-163.

Cherubini E, Gaiarsa JL, Ben-Ari Y (1991) GABA: an excitatory transmitter in early postnatal life. Trends Neurosci 14:515-519.

Choi DW (1988) Glutamate neurotoxicity and diseases of the nervous system. Neuron 1:623-634.

Ciccolini F, Svendsen CN (1998) Fibroblast growth factor 2 (FGF-2) promotes acquisition of epidermal growth factor (EGF) responsiveness in mouse striatal precursor cells: identification of neural precursors responding to both EGF and FGF-2. J Neurosci 18:7869-7880.

Contestabile A (2000) Roles of NMDA receptor activity and nitric oxide production in brain development. Brain Res Brain Res Rev 32:476-509.

Curtis DR, Phillis JW, Watkins JC (1959) Chemical excitation of spinal neurones. Nature 183:611-612.

Dam AM (1992) Estimation of the total number of neurons in different brain areas in the Mongolian gerbil: a model of experimental ischemia. Acta Neurol Scand 137:34-36.
Dammerman RS, Kriegstein AR (2000) Transient actions of neurotransmitters during neocortical development. Epilepsia 41:1080-1081.

Deacon TW, Pakzaban P, Isacson O (1994) The lateral ganglionic eminence is the origin of cells committed to striatal phenotypes, neural transplantation and developmental evidence. Brain Res 668:211-219.

de Carlos JA, Lopez-Mascaraque L, Valverde F (1996) Dynamics of cell migration from the lateral ganglionic eminence in the rat. J Neurosci 16:6146-6156.

Deutsch SI, Mastropaolo J, Rosse RB (1998) Neurodevelopmental consequences of early exposure to phencyclidine and related drugs. Clin Neuropharmacol 21:320-332.

Dobbertin A, Gervais A, Glowinski J, Mallat M (2000) Activation of ionotropic glutamate receptors reduces the production of transforming growth factorbeta2 by developing neurons. Eur J Neurosci 12:4589-4593.

Easter Jr SS, Ross LS, Frankfurter A (1993) Initial tract formation in the mouse brain. J Neurosci 13:285-299.

Edmund T, Jessell TM (1999) Progression from extrinsic to intrinsic signaling in cell fate specification: a view from the nervous system. Cell 96:211-224.

Fentress JC, Stanfield BB, Cowan WM (1981) Observation on the development of the striatum in mice and rats. Anat Embryol (Berl) 163:275-298.

Finkbeiner S, Greenberg ME (1996) $\mathrm{Ca}(2+)$-dependent routes to Ras: mechanisms for neuronal survival, differentiation, and plasticity? Neuron 16:233-236.

Fishell G, Mason CA, Hatten ME (1993) Dispersion of neural progenitors within the germinal zones of the forebrain. Nature 362:636-638.

Flint AC, Kriegstein AR (1997) Mechanisms underlying neuronal migration disorders and epilepsy. Curr Opin Neurol 10:92-97.

Fukunaga K, Miyamoto E (1998) Role of MAP kinase in neurons. Mol Neurobiol 16:79-95.

Geisert Jr EE, Frankfurter A (1989) The neuronal response to injury as visualized by immunostaining of class III beta-tubulin in the rat. Neurosci Lett 102:137-141.

Goebel DJ, Poosch MS (1999) NMDA receptor subunit gene expression in the rat brain: a quantitative analysis of endogenous mRNA levels of NR1Com, NR2A, NR2B, NR2C, NR2D and NR3A. Brain Res Mol Brain Res 69:164-170.

Gratzner HG (1982) Monoclonal antibody to 5-bromo- and 5-iododeoxyuridine: a new reagent for detection of DNA replication. Science 218:474-475.

Gundersen HJ, Jensen EB (1987) The efficiency of systematic sampling in stereology and its prediction. J Microsc 147:229-263.

Halliday AL, Cepko CL (1992) Generation and migration of cells in the developing striatum. Neuron 9:15-26.

Harrison PJ (1999) The neuropathology of schizophrenia. A critical review of the data and their interpretation. Brain 122:593-624.

Haydar TF, Wang F, Schwartz ML, Rakic P (2000) Differential modulation of proliferation in the neocortical ventricular and subventricular zones. J Neurosci 20:5764-5774.

Hoffman PL, Rabe CS, Moses F, Tabakoff B (1989) N-methyl-D-aspartate receptors and ethanol: inhibition of calcium flux and cyclic GMP production. J Neurochem 52:1937-1940.

Holmgren P (1925) Points of view concerning forebrain morphology in higher vertebrates. Acta Zool Stockh 6:413-477.

Husi H, Ward MA, Choudhary JS, Blackstock WP, Grant SG (2000) Proteomic analysis of NMDA receptor-adhesion protein signaling complexes. Nat Neurosci 3:661-669.

Ikeda Y, Nishiyama N, Saito H, Katsuki H (1997) GABA $_{A}$ receptor stimulation promotes survival of embryonic rat striatal neurons in culture. Brain Res Dev Brain Res 98:253-258.

Ikonomidou C, Bosch F, Miksa M, Bittigau P, Vockler J, Dikranian K, Tenkova TI, Stefovska V, Turski L, Olney JW (1999) Blockade of NMDA receptors and apoptotic neurodegeneration in the developing brain. Science 283:70-74.

Ikonomidou C, Bittigau P, Ishimaru MJ, Wozniak DF, Koch C, Genz K, Price MT, Stefovska V, Horster F, Tenkova T, Dikranian K, Olney JW (2000) Ethanol-induced apoptotic neurodegeneration and fetal alcohol syndrome. Science 287:1056-1060.

Inoue T, Tanaka T, Takeichi M, Chisaka O, Nakamura S, Osumi N (2001) Role of cadherins in maintaining the compartment boundary between the cortex and striatum during development. Development 128:561-569.

Ivkovic S, Polonskaia O, Farinas I, Ehrlich ME (1997) Brain-derived neuro- 
trophic factor regulates maturation of the DARPP-32 phenotype in striatal medium spiny neurons: studies in vivo and in vitro. Neuroscience 79:509-516.

Jacobs JS, Miller MW (2000) Cell cycle kinetics and immunohistochemical characterization of dissociated fetal neocortical cultures: evidence that differentiated neurons have mitotic capacity. Brain Res Dev Brain Res 122:67-80

Jevtovic-Todorovic V, Todorovic SM, Mennerick S, Powell S, Dikranian K, Benshoff N, Zorumski CF, Olney JW (1998) Nitrous oxide (laughing gas) is an NMDA antagonist, neuroprotectant and neurotoxin. Nat Med $4: 460-463$.

Johnson GV, Jope RS (1992) The role of microtubule-associated protein 2 (MAP-2) in neuronal growth, plasticity, and degeneration. J Neurosci Res 33:505-512.

Kawaguchi Y, Wilson CJ, Augood SJ, Emson PC (1995) Striatal interneurones, chemical, physiological and morphological characterization. Trends Neurosci 18:527-535.

Kitai ST (1981) Anatomy and physiology of the neostriatum. Adv Biochem Psychopharmacol 30:1-21.

Koroshetz WJ, Freese A, DiFiglia M (1990) The correlation between excitatory amino acid-induced current responses and excitotoxicity in striatal cultures. Brain Res 521:265-272.

Kovacs AD, Cebers G, Cebere A, Moreira T, Liljequist (2001) Cortical and striatal neuronal cultures of the same embryonic origin show intrinsic differences in glutamate receptor expression and vulnerability to excitotoxicity. Exp Neurol 168:47-62.

Landwehrmeyer GB, Standaert DG, Testa CM, Penney Jr JB, Young AB (1995) NMDA receptor subunit mRNA expression by projection neurons and interneurons in rat striatum. J Neurosci 15:5297-5307.

Lauder JM (1993) Neurotransmitters as growth regulatory signals, role of receptors and second messengers. Trends Neurosci 16:233-240.

Lavdas AA, Grigoriou M, Pachnis V, Parnavelas JG (1999) The medial ganglionic eminence gives rise to a population of early neurons in the developing cerebral cortex. J Neurosci 19:7881-7888.

Lee MK, Rebhun LI, Frankfurter A (1990) Posttranslational modification of class III beta-tubulin. Proc Natl Acad Sci USA 87:7195-7199.

Levitt P, Harvey JA, Friedman E, Simansky K, Murphy EH (1997) New evidence for neurotransmitter influences on brain development. Trends Neurosci 20:269-274.

Li BS, Ma W, Zhang L, Barker JL, Stenger DA, Pant HC (2001) Activation of phosphatidylinositol-3 kinase (PI-3K) and extracellular regulated kinases (Erk1/2) is involved in muscarinic receptor-mediated DNA synthesis in neural progenitor cells. J Neurosci 21:1569-1579.

Lillien L (1998) Neural progenitors and stem cells: mechanisms of progenitor heterogeneity. Curr Opin Neurobiol 8:37-44.

LoTurco JJ, Owens DF, Heath MJS, Davis MBE, Kriegstein AR (1995) GABA and glutamate depolarize cortical progenitor cells and inhibit DNA synthesis. Neuron 15:1287-1298.

Lovinger DM, White G, Weight FF (1989) Ethanol inhibits NMDAactivated ion current in hippocampal neurons. Science 243:1721-1724.

Luk KC, Sadikot AF (2001) GABA promotes survival but not proliferation of parvalbumin-immunoreactive interneurons in rodent neostriatum: an in vivo study with stereology. Neuroscience 104:93-103.

Marchand R, Lajoie L (1986) Histogenesis of the striopallidal system in the rat. Neurogenesis of its neurons. Neuroscience 17:573-590.

Marin O, Anderson SA, Rubenstein JL (2000) Origin and molecular specification of striatal interneurons. J Neurosci 20:6063-6076.

Mattson MP, Kater SB (1987) Calcium regulation of neurite elongation and growth cone motility. J Neurosci 7:4034-4043.

Mattson SN, Riley EP, Jernigan TL, Garcia A, Kaneko WM, Ehlers CL, Jones KL (1994) A decrease in the size of the basal ganglia following prenatal alcohol exposure: a preliminary report. Neurotoxicol Teratol 16:283-289.

Matus A, Pehling G, Ackermann M, Maeder J (1980) Brain postsynaptic densities: the relationship to glial and neuronal filaments. J Cell Biol 87:346-359.

Memberg SP, Hall AK (1995) Dividing neuron precursors express neuronspecific tubulin. J Neurobiol 27:26-43.

Metin C, Deleglise D, Serafini T, Kennedy TE, Tessier-Lavigne M (1997) A role for netrin-1 in the guidance of cortical efferents. Development 124:5063-5074.
Mihic SJ (1999) Acute effects of ethanol on GABAA and glycine receptor function. Neurochem Int 35:115-123.

Misgeld U, Dietzel I (1989) Synaptic potentials in the rat neostriatum in dissociated embryonic cell culture. Brain Res 492:149-157.

Moller A, Strange P, Gundersen HJ (1990) Efficient estimation of cell volume and number using the nucleator and the disector. J Microsc 159:61-71.

Monyer H, Burnashev N, Laurie DJ, Sakmann B, Seeburg PH (1994) Developmental and regional expression in the rat brain and functional properties of four NMDA receptors. Neuron 12:529-540.

Moody SA, Quigg MS, Frankfurter A (1989) Development of the peripheral trigeminal system in the chick revealed by an isotype-specific anti-betatubulin monoclonal antibody. J Comp Neurol 279:567-580.

Morrell MJ (1999) Epilepsy in women: the science of why it is special. Neurology 53:S42-48.

Nansen EA, Jokel ES, Lobo MK, Micevych PE, Ariano MA, Levine MS (2000) Striatal ionotropic glutamate receptor ontogeny in the rat. Dev Neurosci 22:329-340.

Olney JW (1982) The toxic effects of glutamate and related compounds in the retina and the brain. Retina 2:341-359.

Oorschot DE (1996) Total number of neurons in the neostriatal, pallidal, subthalamic, and substantia nigral nuclei of the rat basal ganglia, a stereological study using the Cavalieri and optical dissector methods. J Comp Neurol 366:580-599.

O’Rahilly R, Müller F (1994) The embryonic human brain: an atlas of developmental stages. New York: Wiley-Liss.

Parnavelas JG (2000) The origin and migration of cortical neurones, new vistas. Trends Neurosci 23:126-131.

Paxinos G, Watson C (1986) The rat brain in stereotaxic coordinates, Ed 2. San Diego: Academic.

Perkinton MS, Ip JK, Wood GL, Crosswaithe AJ, Williams RJ (2002) Phosphatidylinositol 3-kinase is a central mediator of NMDA receptor signaling to MAP kinase (Erk1/2), Akt/PKB and CREB in striatal neurones. J Neurochem 80:239-254.

Petersen A, Castilho RF, Hansson O, Wieloch T, Brundin P (2000) Oxidative stress, mitochondrial permeability transition and activation of caspases in calcium ionophore A23187-induced death of cultured striatal neurons. Brain Res 857:20-29.

Platénik J, Kuramoto N, Yoneda Y (2000) Molecular mechanisms associated with long-term consolidation of the NMDA signals. Life Sci 67:335-364.

Pleasure SJ, Anderson S, Hevner R, Bagri A, Marin O, Lowenstein DH, Rubenstein JL (2000) Cell migration from the ganglionic eminences is required for the development of hippocampal GABAergic interneurons. Neuron 28:727-740.

Puelles L, Rubenstein JL (1993) Expression patterns of homeobox and other putative regulatory genes in the embryonic mouse forebrain suggest a neuromeric organization. Trends Neurosci 16:472-479.

Puelles L, Kuwana E, Puelles E, Bulfone A, Shimamura K, Keleher J, Smiga S, Rubenstein JL (2000) Pallial and subpallial derivatives in the embryonic chick and mouse telencephalon, traced by the expression of the genes Dlx-2, Emx-1, Nkx-2.1, Pax-6, and Tbr-1. J Comp Neurol 424:409-438.

Rakic P, Komuro H (1995) The role of receptor/channel activity in neuronal cell migration. J Neurobiol 26:299-315

Reich DL, Silvay G (1989) Ketamine: an update on the first twenty-five years of clinical experience. Can J Anaesth 36:186-197.

Reynolds BA, Weiss S (1992) A multipotent EGF-responsive striatal embryonic progenitor cell produces neurons and astrocytes. J Neurosci 12:4565-4574.

Roceri M, Molteni R, Fumagalli F, Racagni G, Gennarelli M, Corsini G, Maggio R, Riva M (2001) Stimulatory role of dopamine on fibroblast growth factor-2 expression in rat striatum. J Neurochem 76:990-997.

Rossi DJ, Slater NT (1993) The developmental onset of NMDA receptorchannel activity during neuronal migration. Neuropharmacology 32:1239-1248.

Sadikot AF, Burhan AM, Belanger MC, Sasseville R (1998) NMDA receptor antagonists influence early development of GABAergic interneurons in the mammalian striatum. Brain Res Dev Brain Res 105:35-42.

Sanes DH, Reh TA, Harris WA (2000) Development of the nervous system. San Diego: Academic.

Schultze B, Nowak B, Maurer W (1974) Cycle times of the neural epithelial 
cells of various types of neuron in the rat. An autoradiographic study. J Comp Neurol 158:207-218.

Schwarzschild MA, Cole RL, Meyers MA, Hyman SE (1999) Contrasting calcium dependencies of SAPK and ERK activations by glutamate in cultured striatal neurons. J Neurochem 72:2248-2255.

Seki T, Arai Y (1995) Age-related production of new granule cells in the adult dentate gyrus. NeuroReport 6:2479-2482.

Shimamura K, Hartigan DJ, Martinez S, Puelles L, Rubenstein JL (1995) Longitudinal organization of the anterior neural plate and neural tube. Development 121:3923-3933.

Sidman RL, Miale IL, Feder N (1959) Cell proliferation and migration in the primitive ependymal zone: an autoradiographic study of histogenesis in the nervous system. Exp Neurol 1:322-333.

Simon DK, Prusky GT, O'Leary DD, Constantine-Paton M (1992) $\mathrm{N}$-methyl-D-aspartate receptor antagonists disrupt the formation of a mammalian neural map. Proc Natl Acad Sci USA 89:10593-10597.

Smart IHM, Sturrock RR (1978) Ontogeny of the neostriatum in the neostriatum (Divac I, Oberg RGE, eds), pp 127-146. Oxford: Pergamon.

Smith AD, Bolam JP (1990) The neural network of the basal ganglia as revealed by the study of synaptic connections of identified neurones. Trends Neurosci 13:259-265.

Stevens CF, Tonegawa S, Wang Y (1994) The role of calcium-calmodulin kinase II in three forms of synaptic plasticity. Curr Biol 4:687-693.

Tabakoff B, Rabe CS, Hoffman PL (1991) Selective effects of sedative/hypnotic drugs on excitatory amino acid receptors in brain. Ann NY Acad Sci 625:488-495.

Tamamaki N, Fujimori KE, Takauji R (1997) Origin and route of tangen- tially migrating neurons in the developing neocortical intermediate zone. J Neurosci 17:8313-8323.

Temple S, Qian X (1995) bFGF, neurotrophins, and the control or cortical neurogenesis. Neuron 15:249-252.

van der Kooy D, Fishell G (1987) Neuronal birthdate underlies the development of striatal compartments. Brain Res 401:155-161.

Ventimiglia R, Lindsay RM (1998) Rat striatal neurons in low-density culture. In: Culturing nerve cells, Ed 2 (Banker G, Goslin K, eds), pp 371394. Cambridge MA: MIT

Vexler ZS, Ferriero DM (2001) Molecular and biochemical mechanisms of perinatal brain injury. Semin Neonatol 6:99-108.

Vincent SR, Sebben M, Dumuis A, Bockaert J (1998) Neurotransmitter regulation of MAP kinase signaling in striatal neurons in primary culture. Synapse 29:29-36.

Watkins JC (2000) L-glutamate as a central neurotransmitter: looking back. Biochem Soc Trans 28:297-309.

West MJ, Ostergaard K, Andreassen OA, Finsen B (1996) Estimation of the number of somatostatin neurons in the striatum, an in situ hybridization study using the optical fractionator method. J Comp Neurol 370:11-22.

Wullner U, Standaert DG, Testa CM, Penney JB, Young AB (1997) Differential expression of kainate receptors in the basal ganglia of the developing and adult rat brain. Brain Res 768:215-223.

Yuste R, Katz LC (1991) Control of postsynaptic $\mathrm{Ca}^{2+}$ influx in developing neocortex by excitatory and inhibitory neurotransmitters. Neuron 6:333-344.

Zilles K (1985) The cortex of the rat. A stereotaxic atlas. New York: Springer. 